\begin{tabular}{|l|l|l||}
\hline \multicolumn{2}{|c|}{ PublisherInfo } \\
\hline \hline PublisherName & $:$ & BioMed Central \\
\hline \hline PublisherLocation & $:$ & London \\
\hline \hline PublisherImprintName & $:$ & BioMed Central \\
\hline \hline
\end{tabular}

\title{
Epithelial pathway revealed
}

\begin{tabular}{|l|l|l||}
\hline \multicolumn{2}{|c|}{ ArticleInfo } \\
\hline \hline ArticleID & $:$ & 5069 \\
\hline \hline ArticleDOI & $:$ & $10.1186 /$ gb-spotlight-20050318-01 \\
\hline \hline ArticleCitationID & $:$ & spotlight-20050318-01 \\
\hline \hline ArticleSequenceNumber & $:$ & 45 \\
\hline \hline ArticleCategory & $:$ & Research news \\
\hline ArticleFirstPage & $:$ & 1 \\
\hline \hline ArticleLastPage & $:$ & 3 \\
\hline \hline & & RegistrationDate : 2005-3-18 \\
\hline ArticleHistory & $:$ & OnlineDate \\
\hline \hline ArticleCopyright & $:$ & BioMed Central Ltd2005-3-18 \\
\hline \hline ArticleGrants & $:$ & \\
\hline \hline ArticleContext & $:$ & 130596611 \\
\hline \hline
\end{tabular}


A molecular signaling pathway once thought to maintain cell survival actually helps control epithelial cell shape and organization, U.S. and German researchers show in two fruit fly studies published by Science this week.

"In nature, different organisms sculpt epithelial sheets into a bewildering array of forms, but relatively little is known about the mechanisms involved," co-author Matthew Gibson of Harvard University told The Scientist. "This pathway or related ones could perhaps have conserved function in epithelial morphogenesis in other organismal systems."

Gibson and senior coauthor Norbert Perrimon screened for genetic factors that control epithelial cell shape during Drosophila wing development. They used a tissue-specific Gal4 driver to direct expression of flipase in wing epithelia at different stages of development. This catalyzed mitotic recombination between a mutagenized chromatid bearing a flipase recombination target and its green-fluorescent protein (GFP) tagged homolog, producing both a homozygous mutant GFP-negative cell and a paired cell bearing two copies of GFP.

One experimental line developed defects in establishing or maintaining pseudostratified columnar shape in medial regions of the wing imaginal disc, resulting in cystlike epithelial extrusions. Recombination mapping against a set of P-element insertions pinpointed the mutation to cytological interval 25D-25F, which bears the decapentaplegic (DPP) receptor thickveins ( $t k v$ ) crucial for imaginal disc development. Another mutant $t k v$ allele and an allele of a downstream signal transducer mad 12 led to extrusion as well, linking this phenotype to defective DPP signaling and not a unique effect of the allele identified in their study, dubbed tkv-extruded.

Independently, Jie Shen and Christian Dahmann at the Max Planck Institute of Molecular Cell Biology and Genetics in Dresden, Germany, investigated what role decapentaplegic (DPP) plays in wing epithelial cells. Prior experiments suggested DPP's role was to control cell survival, since reduced DPP signaling activated the JNK stress signaling pathway and apoptosis. Shen and Dahmann analyzed tkv jnk double mutants within developing wing epithelia via flipase recombination techniques.

"It is surprising to see that mutant cells extruded from the epithelial sheet can survive and even differentiate," Dahmann said. Both research teams found mutant $t k v$ extruded cells often survived to metamorphosis, challenging the view of DPP as survival factor. Instead, the researchers suggest DPP has a more direct role in controlling epithelial morphogenesis.

The U.S. team found that prior studies often triggered recombination with heat shock instead of a tissue-specific driver, suggesting that either heat shock enhanced $t k v$ clone death or the tissue-specific method enhanced clone viability. When Gibson and Perrimon increased background JNK activity with a mutant regulatory phosphotase, their $t k v$ mutants were completely eliminated.

"The Gibson and Perrimon paper shed light on why DPP's function was obscured before in a welltrodden path of experiments by this heat shock protocol that puts cells in a stressful condition when they were sensitive," said Alfonso Martinez-Ariasat the University of Cambridge, who did not participate in these experiments. 
Both research teams found that in stained micrographs, $t k v$ mutants had greatly reduced apical microtubule cytoskeletal networks and F-actin rearranged in the cell. "It supports findings of ours in the last year, where we found a role for DPP in regulating the cytoskeleton in the developing Drosophila embryo," Martinez-Arias told The Scientist.

Future research will involve further genetic screens and transcriptional profiling experiments designed to connect the DPP pathway with morphogenesis effectors, particularly molecules that could influence the integrity of the apical microtubule cytoskeleton and F-actin meshwork.

"This work is screaming for someone to look for any GTPases regulated by DPP," since GTPases regulate the cytoskeleton, said Valerie Weaver of the University of Pennsylvania, who did not participate in these experiments.

While extrusion could result from cytoskeletal effects, "it is just as likely that extrusion is due to an underlying defect in cell adhesion and the cytoskeletal effects are secondary," Gibson added. "We're interested in possible roles for cell-matrix interactions."

\section{References}

1. M.C. Gibson and N. Perrimon. "Extrusion and death of DPP/BMP-compromised epithelial cells in the developing Drosophila wing." Science 307: 1785-9, March 18, 2005., [http://www.sciencemag.org]

2. J. Shen and C. Dahmann. "Extrusion of cells with inappropriate Dpp signaling from Drosophila wing disc epithelia." Science 307: 1789-90, March 18, 2005., [http://www.sciencemag.org]

3. Norbert Perrimon, [http://www.hms.harvard.edu/dms/bbs/fac/perrimon.html]

4. Christian Dahmann, [http://www.mpi-cbg.de/research/groups/dahmann/dahmann.html]

5. Alfonso Martinez-Arias, [http://www.gurdon.cam.ac.uk/phd/groups/martinez-arias.html]

6. Valerie Weaver, [http://www.uphs.upenn.edu/ime/weaver.shtml] 